\title{
Letting Go
}

Claire Smith

University of Victoria

Much has been written about the sense of hope that children give us as parents. Children fill our lives with care in all senses of the word and engender in us a vital sense of purpose. What happens when we have to separate from our offspring? What is the experience of "letting go" like for the mother who has spent so many years nurturing her child? The ancients realized the strength of the mother-child relationship and the turmoil that can ensue when the relationship is severed. In the Greek myth of Demeter (mother-Earth) and her separation from Persephone, her daughter, the earth itself withers and dies until Persephone is returned to her mother; and even then, for the winter months when Persephone must return to the Underworld, the earth languishes, barren and cold. This myth, of course, springs from the untimely separation of mother and child. It does, nevertheless, serve to illustrate the primal connection of mother and child and the pain that can be felt as a result of bonds being severed.

Like Janus, the two-faced Roman God, guardian of exits and entrances, the mother stands at the gate, looking forward and backward as her child leaves the home. As she encourages him to exit, yet would she hold him back with her within the protective gates. Mothers applaud their children's progress and eagerly anticipate their next stage of independence: Now he can stand up by himself! Walk! Talk! Play outside with other children, go to school-and so on. Yet as the child grows older, the mother starts also to glance backward. Where is the time going? When the forward journey to adulthood has been completed, her feelings are often fraught with ambiguity. She is happy that her mission as guide and essential nurturer is successfully completed. She has discharged her labor of love well enough for her child to continue on the journey alone. And yet she now looks back at that far from easy, but exciting and purposeful journey with a sense of regret and nostalgia. Roads must part. Farewells take place. They will meet again, but they will never travel as far again together. How do we, as mothers, come to terms with this experience? How do we understand better this phase of parenting?

\section{Separation as Preparation}

Birth itself is the first physical separation from her child that the mother experiences. The umbilical cord is cut; later the child is weaned from the breast. The word sever is etymologically closely 
linked with the term "wean," because both denote a cutting off from the source. The Middle French word severer means "to wean" and both are synonyms for "separate" (Partridge, 1983). From this time on the child is moving gradually away from the mother, at times imperceptibly, at other times perceptibly. Going to school for the first time is one such memorable moment, and many mothers shed a few tears as their babies enter this new world out of their sphere of influence.

I remember walking Peter to school on his first day. I had mixed feelings, but he was very excited. As we arrived at the school, I kissed him goodbye, told him he would have a great day, and reminded him I would see him at lunch-time. He trotted off happily with his new friend. But then he stopped and called, "You should go downtown, so you won't be lonely without me there." Then he waved and disappeared. What amazed me was that not only I, but my child also, had sensed that for me this would be a loss. Contrary to my expectations, I was not the one consoling my child as he left the home: the roles were reversed! ${ }^{1}$

These early separations which foreshadow the later ones may be painful too. Anne, another mother, recalls her child being kept for several days in an isolation ward in hospital and having to leave him crying and alone.

I got into the elevator and wept all the way down. I felt torn apart inside.

I felt worse when I saw that there were Christmas trees in the lobby.

On the other hand, these intimations of our children leaving may be only brief moments of recognition. A mother remembers, for instance, the first time her child sleeps over at a friend's. While the mother tidies up the empty room, there is the faint stirring of uneasiness, unspoken as yet. What a relief when the room is once more inhabited! The toys rescattered, the bed disheveled and imprinted with the warm shape that tumbles out in the morning.

Sometimes these poignant inklings of the future stem from a sudden awareness of time.

I remember on a lovely golden September day, looking out of the window and seeing my three year old daughter swinging back and forth by herself under the huge willow at the bottom of the garden. Her hair streamed out behind her catching the sunlight and she was swinging alternately into dappled shadow and bright light. She was singing gustily but tunelessly to herself, happily lost in her own world. Looking at her at that moment the shadow crossed my mind that she soon must leave this charmed world of childhood.

Sometimes there is the premonition of separation for no reason other than a moment of recognition of the ephemeral nature of childhood. Maybe in our memories we freeze moments in time, to 
store up like photographs for the times when we want to recall our absent children. Of course, we also take prodigious numbers of "real" photographs, capturing every significant stage in our children's life, preparing for our separation from them.

Examining the roots of the word "to separate" shows that in both Latin, separare, and in the Old French, se pare, the word meant "to prepare" (Partridge, 1983). Certainly in connection with the separation of mother and child we are constantly being prepared for the leave-taking of the child. During the adolescent years this preparation seems to intensify and mothers notice their children moving away emotionally, more influenced by other friends and separate interests, bored by and even disapproving of their parents' activities and interests.

Sheila recalls her teenage child seemingly transformed into another person at the age of 13:

Our daughter became unrecognizable. Her behavior at times seemed almost insane. She was so difficult to live with over those years that it made us very ready to separate.

In this instance the preparation for separation was the true separation and far more painful than the physical departure from the home of Sheila's daughter five years later.

Speaking of that often painful metamorphosis of child into adult, Roy (1977) writes in her novel Children of My Heart, "I felt that I was spectator to the death of a child under pressure from the man to whom he was giving birth" (p. 160).

As parent (or teacher) we experience vicariously those pangs of our children being delivered into adulthood, but ultimately we have to stand back and encourage them, knowing that it is an important step away from us to a new world.

\section{Farewell/The Leave-Taking}

Although, as mothers, we are gradually prepared for separation, there comes a moment perhaps clearer than any other when we sense the significant leave-taking: The point of departure has been marked. This moment may be recognized instantaneously by both mother and child, or it may be realized by only one, or be acknowledged only in retrospect as the true denouement of the parental knot.

For myself, the realization came when my son was to leave the Island to go to University in Vancouver. He found, with the help of a friend, his own apartment. He was adamant in his determination to find the apartment himself. I felt excluded and inwardly hurt that my help was not wanted, or more importantly, not needed. After all, what experience did he really have in such practical affairs? As I offered unwanted advice and assistance the look in my son's eyes grew more and more distant. "Come 
and help if you feel you must," he finally muttered. Put into those words, the painful truth of my need, not his, struck me. Peter found his own apartment with ease and took care of all practical issues like a veteran! When we took him to the ferry in September, I felt as if he was truly leaving us behind this time-even though we would see him in a few weeks. Tall and detached, he seemed to avoid looking at us as we hugged him good-bye. But then he turned to us and unexpectedly and uncharacteristically there were tears in his eyes. He hugged us again very tightly, and left. I knew that he too saw this as "leaving home."

The setting up of a separate home embodies, in a very concrete and obvious way, the notion of dwelling apart. Maybe unconsciously for my son it was extremely important for him to do this alone, on his own terms. My "help" was seen (quite rightly!) as an unwillingness to step out of his way. I did feel, though, very strongly, that if our son was to leave our home I wanted to somehow influence or be a part of that new place he was going to.

When Judy's son left, she did not immediately recognize that this was the significant point of departure. At 16, Chris was still her baby. $\mathrm{He}$ was going to college in a different country and the pangs of leaving were very real to her.

The whole family had a farewell breakfast together in a charming little old Welsh hotel. Chris came down to breakfast, late and with red eyes. But it was only later, after we had left Chris and gone back to the car, that we found he had left us each a farewell letter. Chris saw this leave138 taking as a very significant moment of separation, although for myself, at the time, I did not perceive it as such. It was a bittersweet experience to read the letters which thanked us for being such good parents and outlined our son's hopes for the future. I knew then that my son was "cutting the cords." Sitting in the car reading my letter, I wept.

Sharon remembers the time her 17-year-old daughter left for Australia:

That was the worst feeling of separation I ever had. For a week before she left, neither of us could look at each other or speak civilly. I think we were trying to make ourselves immune. At the airport, it was devastating. My daughter is an epileptic. "Don't forget to take your pills," I kept saying. After she left, I kept worrying about her but reminding myself that she had to learn to protect herself. She came back the following year, and she had grown independent even though we maintained a close relationship.

Thus it is that mothers sooner or later recognize that the time has come for their children to physically leave the home. They will still come back, but they will come back changed. As I have mentioned earlier, the physical leave-taking is not always the significant point of departure. In Sheila's case the separation at a more profound level had occurred much earlier. Her daughter was in fact asked to leave because her behavior was causing so much disruption in the home. Sheila's daughter left because her presence was more painful 
than her physical absence would be to her parents. After a year she returned to them in both body and spirit. That physical distance had allowed a healing process to take place. Now she is leaving once more, but this time in happier circumstances and as a daughter they can converse with.

Sheila's perception that it was the right time for her daughter to leave seemed an accurate one. For the most part, we have to acknowledge the sadness of this real leave-taking, but it is worth looking also at its antinomy. What happens when children or parents don't "let go," when the child does not undertake the journeyphysical or emotional? Doreen speaks of her sister's son:

My nephew, who is 18, does not want to leave home. He stays in bed until noon and expects his mother to wait on him. He has no ambitions, no sense of purpose, and relies on his mother to take responsibility for him. His mother is very worried about him, especially as he is unhappy and depressed. I want to tell him "Get on with your own life. Your mother needs a space for herself too." The trouble is he is still being treated as a child.

In this situation the mother feels no pangs of separation, but both she and the child are unhappy because he is unable to take those steps forward into adulthood. Considering the consequences of not "letting go" makes us realize the importance and inevitability of this process, if the relationship between mother and child is to progress beyond a fruitless clinging on to yesterday. To continue with the consideration of the actual time of physical separation, it would seem appropriate to describe, at this point, how we react to the empty spaces left by our children's departure.

\section{The Empty Nest}

The young bird after practicing flight finally spreads its wings and flies from the nest. How many of our colloquial expressions express this notion of the child leaving home! In the bird world, the nest is usually deserted once the young have left, as it has fulfilled its purpose. More complex is the human reality, but the sense of the house (built as a home to raise children) being deserted is surely there.

When we returned from the ferry terminal after bidding farewell to our son, the silence of our house seemed almost sepulchral. Both our children had gone within such a short time span. We sat at the table where there had always been four, now only two facing each other across the table, making polite conversation. We put the record player on.

In a similar situation, a friend tells me, she and her husband ate hurriedly and silently and then went straight to bed. The silence after the cheerful or at least noisy chatter of children, can seem deafening. "We are rattling around in the house," goes the common saying. Aside from the onomatopoeia of the word "rattle," its connotations 
are most likely not accidental in this context. It is a hollow sounding word indeed, with overtones of the dry brittleness associated with bones and death! The word also conveys a sense of aimlessness "rattling around"-as if trying to redefine our sense of purpose and reorient ourselves to this different space.

Doreen comments on the orderliness of the house. No clothes or junk lying around! No drawers full of socks, or shoes left to trip over. How is it we seem to miss now those very things that used to cause us irritation?

The rooms, the bedrooms, once occupied by our children, have a special poignancy especially in that time immediately following the child's departure. Many mothers would empathize with the description in Anne of Green Gables of Marilla's feelings after her beloved foster child Anne goes away.

Marilla plunged fiercely into unnecessary work ... but that night when Marilla went to bed, acutely and miserably conscious that the little gable room at the end of the hall was untenanted by any vivid young life and unstirred by any soft breathing, she buried her face in her pillow and wept for her girl. (Montgomery, 1935, p. 269)

Clean, tidy, and empty, the children's rooms are often left untouched, waiting for the return of their former occupants. To remind them of their children some mothers display their photographs more prominently around the house. But Doreen recalls how for a while after her children left she did not want photographs of them around. She did not, it seemed, want to be reminded by facsimiles of her children. If they could not be really there, maybe she wanted to be able to forget them for a while.

But Judy played a record to remind her of Chris; a special record he had made of all the children at his school singing songs from around the world. Whenever Judy missed her son, the void was partially filled by the sound of those young voices floating through the house.

How else do we adjust ourselves to our changed space? When we coincidentally decided to renovate and expand our kitchen and dining room after our children left, I was surprised to be asked by a salesman "Have your children just left home?" To my startled response he explained, "A lot of our customers seem to redo their kitchens when the kids leave. It's a funny thing!" It is a "funny thing" indeed. Both our kitchen and dining room are now spacious, filled with sunshine and face out to sea. Of course, we thoroughly rationalized this decision, but it does seem ironic that this "heart of the house" (the kitchen) is bigger than it was before, and we have larger areas in which to prepare and eat food. Indeed, many parents build bigger houses altogether. Is this a kind of charm to ward off the specter of impending loneliness? Are the rooms an invitation to be filled? A preparation for the "extended" family? The attempt to 
change the space, to renovate, or restructure seems a positive way to deal with the pangs of separation. It is a step toward change and the future, a move against the house becoming, metaphorically, a kind of mausoleum.

\section{Childhood's End/The Sense of Loss}

William Gibson, the playwright, speaking of his rebellious 16-yearod son who has left home, writes: "For years I have been mourning and not for my dead, it is for this boy for whatever corner in my heart died when his childhood slid out of my arms" (1974, p. 38).

When children leave what do we mourn for? We do not mourn because they have become adults. We are proud of them and their accomplishments. We have in fact aided them in that process of natural growth. For when that does not happen, what is left but a stunting, a stagnation of life? It is not the new adult we regret, nor the leaving of that new adult even, so much as the farewell to childhood. One of the sad ironies of life is that we often do not truly value things so much as when we have lost them. As we wave good-bye to our children at the airport or the altar, that only brings more clearly into focus what we already know has left us; it simply underscores that sense of loss of our deeply personal contact with and investment in children.

Doreen reflects:

I grew up with my children. I had them when I was young and for so many years it seemed they were my life. We played together. We learned together. When they left, I felt I had lost part of myself. I put so much of myself into raising my children.

As Sheehy (1976) aptly phrases it: "When children pull out their roots, they can be felt as being pulled out of our hearts" (p. 423). Is it perhaps, then, that we mourn the loss of part of ourselves as much as the "loss" of our children (whom in one sense we have never truly lost)? We know that hanging on to the child-becoming-adult is a futile and self-defeating task. What is it then but a final protest against the slipping away of that gift of childhood that was entrusted to us for such a short time and which changed our outlook on life so fundamentally? The mother now has to face a new life without the children who have provided those fascinating glimpses into the heart of things. It is that sense of renewal, wonder, and learning that in the midst of all the frustrations, anxieties, and hard work of parenting, remain most of all etched in our being.

When Doreen realized her two boys were fast growing out of childhood, her immediate reaction was "No! I am too young to live yet without children and childhood." Doreen had another child who has kept her "in touch with" that vital sense of life. 
I have so much fun with him. When you are with a child you feel you can do anything. I can play with the toys in toy shops, kick a ball around, anything. As an adult, you need no excuse to do those things when you have a child.

It seems that children help us to stay in touch with the child in ourselves which, as we grew into adulthood, we thought we had lost.

Through children our lives are revitalized and renewed. We not only teach our children but they teach us--and often in very concrete ways. I am reminded of a child I know who is teaching his parents to use a computer so they can "keep up." Just the other day I overheard a conversation between mother and son in a bookstore in Victoria. The young boy was thanking his mother enthusiastically for the books she had bought him. She put her arm around him and said, "And I want to thank you for bringing me to this wonderful shop. I've never been here before and I got all the books I wanted myself!" They left the store arm in arm looking very pleased with each other. Parents and children sustain and nurture each other. As mothers, we are able to recapture the magic of Christmas or birthdays, for example, or in fact of most experiences that from our adult perspective have become somewhat jaded, but which to the child are wondrous and new.

Separation from this state of childhood and from our children means a change in ourselves and in our own outlook on life. Writes Roy (1977) as she describes the final parting with her beloved pupils:

I had before me a world of discoveries but I realized that behind me there already lay things that were forever lost... For the first time I was aware that in order to advance one step, one must tear oneself away from some possession perhaps even more precious. (p. 162)

\section{Ceremony}

Exits are often also entrances, and endings mark beginnings. How often are separations divisions which result in the production of another? Phoenix-like, new life emerges from the death of the old, and we celebrate loss and endings very often because they are inextricably a part of beginnings and growth. Thus we dignify and salute our endings as the foundations for new creations. Even funerals become not only ceremonies of farewell but also in their original intent a celebration of the soul's departure into a higher state of being.

In North America the high school graduation ceremonies become a highly charged emotional event for both parent and child. They mark the end of childhood as defined by the end of schooldays and at the same time, of course, celebrate the transition into adult life. They are simultaneously a farewell and a "coming of age" salute to our children. 
My husband and I sat in the packed auditorium and craned our necks like all the other parents to pick out our son from the dazzling parade of splendidly dressed young adults, some self-conscious and awkward in this new formal attire, others comfortable in the new clothes. A hush came over the audience, perhaps at the transformation each saw in his own child, transfigured, for an evening at least, into an adult. Gone the careless uniform of jeans and sneakers, instead this amazing display of style and individuality. Parents wave and point as they spot their children, but mostly the young adults look ahead or whisper to each other. Some wave back briefly if they spot a parent. We catch sight of our son, a handsome young stranger in suit, tie, and leather shoes! He does not see us; he is chatting to a friend, laughing but looking around with a little uncertainty. I sense the excitement but also the vulnerability. Gasps of delight and ripples of applause around the auditorium. Mothers around me are dabbing their eyes and blowing their noses, feeling that "sweet sorrow" that overwhelms us at such moments. Our son's name is called. For once he has heeded my advice and is not slouching! Standing tall, he receives more awards than my husband or I have ever achieved! Where did he get all these talents from? I clap hard with everyone else, a spectator from a distance. Is this really my son? The choir sings about the "roads of life" and the challenges ahead. Each student passes through a flower-strewn archway. The cameras flash, preserving this significant moment. After the ceremonies, we are reunited briefly with our children. Hugs, congratulations, photographs. And then the young ones go off into the night to their grad parties to celebrate together. We parents get together for a drink afterward. We are cheerful as we talk of the ceremony and congratulate each other. But there is an unspoken wistfulness lurking behind our bright chatter, and we all go home quite early.

Such a ceremony is no doubt a poignant moment for mothers (and fathers!). But one senses the wisdom of ceremonies to mark these transitions in life. They give us a sense of the universality of our experience. I am only one of many mothers, bidding farewell to my child with a sadness tempered by joy at his safe arrival on the threshold of adulthood. This ceremony, moreover, helps to distance me from my child, to let him go with the due regard, pomp, and circumstance which are appropriate to celebrate his accomplishments and his growth to manhood. The ceremony, which affirms for him the rightness of striding out to greet life, also eases the break for us. It dignifies our individual losses and makes us feel more at one with the world's way.

So it is that farewells delivered at railway stations, airports, and docksides seem to be imbued with metaphoric meaning, so much have they become in our mind, the very symbols of life's transitions and separations from those we love. My children leave on a ferry from the "safe harbor" of their "island home." In Boeing 747s they "fly from the nest." It was in a large ocean liner that I left my own parents waving from the port, as I embarked on a new "voyage of life" to the "new world" leaving the "old country" behind me. And when large ships glide out to sea, traditional bands often play the stirring music of the native land. As the ship eases away from the 
shore, the gap between the waving families widens, but the music floats consolingly back and forth between ship and shore, soothing the rupture with ceremony. Turning at last from those faint receding figures, the young voyager sighs and turns forward to face the exciting journey ahead. Those left behind face outward as well, following with their hearts.

\section{The Continuing Link}

In her role of pedagogue, Roy (1977) concludes her description of separating from the little group of Prairie children:

The time had come to separate for good from these children whom I had held as close to my heart as if they had been my own. But what am I saying? They were mine and would be even when I had forgotten their names and faces, remaining a part of me as I would be a part of them, by virtue of the most mysterious possessive force. (p. 163)

In spite of the pangs of separation, most mothers would feel, as Roy does, that their link with their children will always be there in spite of physical absence.

Judy expresses it this way:

I have never felt truly separated from Chris. We are, of course, not as close as we used to be but I will never "let him go" emotionally. I may see

144 him less and less. He may leave the country, but I always imagine having that link.

Sheila comments:

You never stop being a mother. I used to think that when your children left you were free from care, but you never stop caring for your children.

And Sharon reflects:

My daughter went away but she came back. We still have a strong relationship and enjoy each other's company. My son and I still enjoy the same things as we always did and we still share the same anxieties.

The telephone, in practical terms, is a great maintainer of that emotional link. Mothers phone their children regularly to stay in touch. Doreen notes that if she doesn't hear from her boys, she phones them to keep in touch. I know that we phone our children wherever they are, and sometimes have more intense and uninterrupted conversations than when they are actually here.

It is indeed difficult to consider motherhood as a phase or stage of our life, even though some sociological texts seem to imply this. Motherhood alters our very being and becomes a part of us. Although we lose our children in one sense, in another sense we never truly lose them. Moreover, that connection we have with our 
children is the link that we have forged with the future, our investment in life. Marcel expresses this notion in reference to the ultimate separation of death. The man who sacrifices himself for his child does so, surely, in the belief of a suprapersonal unity with his child. Thus even death cannot break the link because he believes he will survive through his child (Marcel, 1951).

A recent film, Eleni, based on the autobiographical novel of Cage (1985) also contains something of this notion of an unbreakable bond between mother and child, even in death. This true story movingly portrays the plight of a mother and her children living in a Greek village successively under siege from Nazis and communist freedom-fighters. Eleni's overwhelming concern is for her children. Politics are not her concern. She fights all attempts-both violent and seductive - to separate her from her children. The children are a source of both anguish and of hope to her, as she works frantically to enable them to escape to America. After a wrenching-but, she believes, temporary parting, Eleni is, shortly afterward arrested for subversive activities. She is thus prevented from fulfilling her plans to escape and join her children in the new world.

The film ends with Fileni and some other dissidents being silently marched to their execution in the hill area surrounding the village. On her way, Eleni passes a child. She stops and looks at him wordlessly, but with such anguished tenderness that it seems he is her own child. As the soldiers raise their rifles and fire, Eleni's last fierce cry echoes and rebounds over the hills: "My children!" The words reverberate with such force and conviction that this haunting tale ends on a note of hope, lending sense to that tragic separation.

In one sense, then, we do indeed lose our children, that is, we separate from them. However, in a deeper sense, they will always be a part of us and we of them, and they ensure in us a sense of continuity.

\section{Notes}

1. Unless otherwise indicated, quotes are anecdotes related to me by mothers in interviews conducted for the purpose of this paper.

\section{References}

Gibson, W. (1974). A season in heaven. New York: Antheneum.

Marcel, G. (1951). The mystery of being. Chicago: Regnery.

Montgomery, L.M. (1935). Anne of Green Gables. New York: Grosset and Dunlap.

Partridge, E. (1983). Etymological dictionary of modern English. New York: Greenwich House. 
Roy, G. (1977). Children of my heart. Toronto: McLelland \& Stewart. Sheehy, G. (1976). Passages. New York: Dutton.

Yates, P. (Director). (1985). Eleni [Film]. (Based on a novel by Nicholas Cage) 